\title{
The Effectiveness of Oil Palm Empty Bunch Compost and Goat Manure on Shallots Cultivated on Red Yellow Podzolic Soil
}

\author{
DOI: $10.18196 /$ pt.v10i1.10621
}

\author{
Marianne Reynelda Mamondol ${ }^{*}$, Amossius Rompolemba Andi Baso Meringgi ${ }^{2}$ \\ Study Program of Agribusiness, Faculty of Agriculture, University of Christian Tentena, Poso, Central Sulawesi, Indonesia \\ *Corresponding author, email: mariannemamondol@gmail.com
}

\begin{abstract}
Red yellow podzolic (RYP) soil is one of the limiting factors in crop cultivation due to its high level of acidity and low content of essential nutrients. This study aimed to explore the effect of oil palm empty bunch (OPEB) compost and goat manure on shallots cultivated on RYP soil, determine the best treatment combination as fertilization recommendation, and analyze the economic feasibility for organic shallot farms. Observations were conducted on soil pH, crop growth, crop yield, shallot farm economic analysis, and the fertilization effectiveness calculation. The results demonstrated that the fertilization had a significant interaction effect on crop height, number of tillers, and fresh and dry tuber weights, but not on the soil pH, number of leaves, and tubers per cluster. A combination of 4 ton/ha compost and 1,00 ton/ha manure resulted in optimal production of dry tubers reaching $0.708 \mathrm{~kg} / \mathrm{plot}$ (2.36 ton/ha). Meanwhile, the highest production of dry tubers of around $0.990 \mathrm{~kg} / \mathrm{plot}$ (3.30 ton/ha) resulted from the combination of 5 ton/ha compost and 1.25 ton/ha manure. Farm analysis showed that organic fertilizer applications provided economic profit, indicated by R/C Ratio value greater than 1. The effectiveness of organic fertilization using compost and manure reached the highest values of $318.90 \%$ and $384 \%$, respectively.
\end{abstract}

Keywords: Effectiveness, goat manure, OPEB compost, RYP soil, shallot

ABSTRAK

Tanah podsolik merah kuning (PMK) merupakan salah satu faktor pembatas budidaya tanaman karena memiliki derajat keasaman tinggi dan rendah kandungan unsur hara esensial bagi pertumbuhan tanaman. Penelitian ini bertujuan untuk menganalisis pengaruh pemberian kompos tandan kosong kelapa sawit (TKKS) dan pupuk kotoran kambing terhadap pertumbuhan dan hasil tanaman bawang merah pada tanah PMK, kombinasi perlakuan terbaik yang dapat menjadi rekomendasi pemupukan, dan kelayakan ekonomi usahatani bawang merah organik. Pengamatan dilakukan terhadap beberapa komponen, yaitu pH tanah, pertumbuhan tanaman, hasil tanaman, analisis ekonomi usahatani bawang merah, dan perhitungan efisiensi pemupukan. Hasil penelitian menunjukkan bahwa perlakuan pemupukan menghasilkan interaksi nyata terhadap tinggi tanaman, jumlah anakan, bobot umbi segar, dan bobot umbi kering, tetapi tidak menghasilkan interaksi nyata terhadap pH tanah, jumlah daun, dan jumlah umbi per rumpun. Kombinasi 4 ton/ha kompos dan 1,00 ton/ha kotoran kambing menghasilkan produksi optimal umbi kering bawang merah 0,708 kg/petak (2,36 ton/ha). Kombinasi 5 ton/ha kompos dan 1,25 ton/ha kotoran kambing menghasilkan produksi tertinggi umbi kering sebesar 0,990 kg/petak (3,30 ton/ha). Analisis usahatani memperlihatkan bahwa penggunaan pupuk organik memberikan keuntungan ekonomi dengan nilai R/C Ratio yang lebih besar daripada 1. Efektivitas pemupukan organik untuk kompos dan pupuk kandang mencapai nilai tertinggi masing-masing sebesar 318,90\% dan 384\%.

Kata kunci: Efektivitas, Pupuk kotoran kambing, Kompos TKKS, Tanah PMK, Bawang merah

\section{INTRODUCTION}

Shallot is an important horticultural commod- (Regency, 2017). This production is lower than ity due to its nutritional content, economic value, yield-per-hectare in Central Sulawesi and shallot's and benefits as a daily cooking spice. One of the shallot-producing regions in Central Sulawesi Province is Poso Regency, comprising North Lore, East Lore, Lore Peore, North Pamona, and Pamona Puselemba Districts. The highest yield-per-hectare is produced in East Lore (4.94 ton/ha), while the lowest one is from North Pamona (0.76 ton/ha) potential productivity, which are 5.31 ton/ha (Sulteng, 2017) and 10-20 ton/ha (Purba, 2016), respectively.

According to Erpina et al., (2013), one of the limiting factors for shallot growth is soil fertility, influenced by the availability of nutrients, organic materials, and soil types. Specifically for 
North Pamona and Pamona Puselemba regions, preliminary surveys indicated that the land used for shallot planting was generally the Red Yellow Podzolic (RYP) soil type, which had high acidity and low N, P, and K contents. Yields and qualities of shallots cultivated on RYP soil and commonly fertilized with NPK were usually very low, ranging from 0.6-0.9 ton/ha or 0.76 ton/ha on average, thus reducing farmers' interest in cultivating them.

Red Yellow Podzolic is a type of soil formed by a pedogenesis process that resembles the formation of latosol soil. It has a soil organic material thickness less than $60 \mathrm{~cm}$, some of which are still decomposing, and has many fibers. Red Yellow Podzolic soil agroecosystem deals with many obstacles, especially dry areas with high slopes because RYP soil is sensitive to erosion (Raiwani et al., 2016). The constraints faced on RYP soil include low soil $\mathrm{pH}$ (4.1-4.8), high $\mathrm{Al}, \mathrm{Fe}$, and Mn solubilities but low $\mathrm{P}$ and Mo availabilities, the dominances of kaolinite clay minerals, Fe oxides, and $\mathrm{Al}$ so that the soil has a low cation exchange capacity, and high mineral contents, which if dissolve will cause cation saturation that is toxic to crops, while the anions are easily fixed so that they become unavailable to crops (Ramadhani et al., 2015).

Due to high rainfall, red Yellow Podzolic soil has undergone further weathering with a very intensive leaching process. The result is low contents of exchangeable bases $(<35 \%)$ and organic materials (C/N ratio 5-10) (Tando, 2020). Red Yellow Podzolic soil requires organic materials to improve the soil's physical, chemical, and biological properties. The addition of organic materials can reduce $\mathrm{Al}$ solubility and enhance the availability of essential nutrients such as N, P, and K (Erpina et al., 2013). According to Tando (2020), RYP soil has the potential to be used as a medium for crop growth because it has a medium to high cation exchange capacity $(>16 \mathrm{cmol} / \mathrm{kg})$, so it helps the fertilization.
In addition, to the cross-sectional conditions of the soil that are deep enough to support crop roots.

Oil palm empty bunch (OPEB) and goat manure are natural ingredients utilized as organic fertilizers. Oil palm empty bunch is the source of organic potassium $(\mathrm{K})$, containing up to $2.90 \%$ (Firmansyah, 2010). The high levels of $K$, which are alkaline, can raise soil $\mathrm{pH}$, reducing soil acidity. For shallot crops, K elements are needed, particularly in tuber formation. The $\mathrm{N}$ content in goat manure reaches $1-2 \%$, stimulating initial crop growth (Prasetyo, 2014). The use of OPEB and goat manure is an effort to use agricultural wastes into efficient products and reduce external farming inputs.

Through the decomposition process, OPEB can be used as fertilizer which high N, P, and $\mathrm{K}$ content (Kurniawan et al., 2014). Nutrients contained in OPEB include $2.90 \% \mathrm{~K}_{2} \mathrm{O}, 0.80 \% \mathrm{~N}$, dan 0.22 $\% \mathrm{P}_{2} \mathrm{O}_{5}$ (Firmansyah, 2010). OPEB compost has a high $\mathrm{K}$ content, which can improve physical, chemical, and biological soil properties and enrich nutrients (Elfiati \& Siregar, 2010). Research results by Sukasih (2017) demonstrated that OPEB application as many as $1.5 \mathrm{~kg} / \mathrm{m}^{2}$ resulted in the best average of spring shallot height per cluster, which was $18.87 \mathrm{~cm}$ and $32.00 \mathrm{~cm}$, respectively, the number of leaves per cluster of 11.40 , and fresh weight per cluster of 102.00 gram.

Livestock manure is the most significant waste produced in animal farming. One method of avoiding environmental pollution caused by livestock waste is to convert it into manure (Kusuma, 2012). Goat manure has an $\mathrm{N}$ content of $1-2 \%, \mathrm{P} 0.8 \%$, and $\mathrm{K} 0.4 \%$. The reasons for using goat manure are that it is easy to obtain, has high $\mathrm{N}$ content, and is a hot fertilizer. Hot fertilizer is a fertilizer whose decomposition is conducted by soil microorganisms so quickly that the nutrients contained in it can be rapidly utilized by crops (Prasetyo, 2014). The problem with manure application is the reluc- 
tance of farmers to use manure because the organic material is available slowly to the soil. Therefore, manure application is directed to fertilizers that have been fermented with bio activators, such as effective microorganisms 4 (EM4), so that they can have a good, fast, and direct effect on crop growth and yield (Suwandi et al., 2015).

Sumarni et al., (2012a) stated that growing and producing shallot crops required adequate and balanced nutrient availability, particularly $\mathrm{N}$ and K. N and K nutrients, which are essential for the growth, development, and yield of shallot bulbs. $\mathrm{N}$ nutrient is a building block for proteins, nucleic acids, enzymes, nucleoproteins, and alkaloids. $\mathrm{N}$ deficiency limits cell division and enlargement. High doses of $\mathrm{N}$ fertilizer do not provide significant results on shallot production. Onion production increases only $32 \%$ if $\mathrm{N}$ application is twice as high as the previous dosage (Napitupulu \& Winarto, 2010). In other words, applying high doses of $N$ fertilizer does not guarantee an increase in yield.

The results of research on shallot fertilization indicate that fertilizer requirements for shallot bulb production vary between $150-300 \mathrm{~kg} / \mathrm{ha} \mathrm{N}, 90-180$ $\mathrm{kg} / \mathrm{ha} \mathrm{P}_{2} \mathrm{O}_{5}$, and $50-150 \mathrm{~kg} / \mathrm{ha} \mathrm{K}_{2} \mathrm{O}$, depending on the variety, growing season, and soil type (Sumarni et al., 2012b). Purba (2016) concluded that the application of inorganic fertilizers and organic fertilizers significantly increased the growth and yield of shallot tubers. The combination of artificial organic fertilizer 5 ton/ha with Urea $100 \mathrm{~kg} /$ ha, SP $36200 \mathrm{~kg} / \mathrm{ha}$, and NPK Phonska $300 \mathrm{~kg} /$ ha gave the highest tuber yield (15.022 ton/ha), $\mathrm{R} / \mathrm{C}$ ratio (1.93), and profit of $\mathrm{Rp} 79,276,000$ per hectare. The value of $\mathrm{R} / \mathrm{C}$ Ratio $>1$ indicates that shallot farming is economically profitable. Through this research we try to point out the effect of organic fertilizer application on both RYP soil and shallot crops, and then to connect the crop yield to the economic profit that might be possible gained by farmers. Therefore the objectives of this research are : 1) to explore the effect of oil palm empty bunch (OPEB) compost and goat manure on shallots cultivated on RYP soil, 2) to determine the best treatment combination as fertilization recommendation, and 3) to analyze the economic feasibility for organic shallot farms

\section{MATERIALS AND METHODS}

This research was conducted from June to November 2020 at the Experimental Field of the Faculty of Agriculture, Tentena Christian University, Pamona Village, Pamona Puselemba District, Poso Regency, at an altitude of $505 \mathrm{~m}$ above sea level. The soil in the experimental location is a type of red yellow podsolic soil (RYP) with an average $\mathrm{pH}$ ranging from 4.0-4.2 (acidic).

The experiment was arranged in a factorial randomized block design which consisted of two factors. The first factor was the dosage of OPEB compost, consisting of five types of treatment, namely 1 ton/ha, 2 ton/ha, 3 ton/ha, 4 ton/ha, and 5 ton/ha. The second factor was the dosage of goat manure with five types of treatments, namely 0.25 ton/ha, 0.50 ton/ha, 0.75 ton/ha, 1.00 ton/ ha, and 1.25 ton/ha.

There were 25 plots of treatment combinations, where each treatment was replicated twice so that there were 50 experimental plot units overall. The experimental plot was $2 \mathrm{~m} \times 1.5 \mathrm{~m}$ in size with a plant spacing of $20 \mathrm{~cm} \times 30 \mathrm{~cm}$. Organic fertilizer was applied to the soil a week before planting the seeds. The fertilizer was evenly mixed with the soil, then left for one week. Maintenance is carried out on plants, including watering, weed controlling, and pest and plant disease controlling. Shallot harvest was carried out when the crops were 60 days after planting.

There were three parameters observed. First, the soil $\mathrm{pH}$ was measured before the treatments 
were applied and at shallot's harvest time (after the treatment application). Second, the crop growth, including the measurements of the crop height $(\mathrm{cm})$ at six weeks after planting (WAP) using a meter from the ground to the highest growing point, the number of crops leaves at 6 WAP, and the number of tillers in each cluster at 6 WAP. Third, the crop yield includes observing the number of tubers per cluster at harvest time, fresh tuber weight per plot $(\mathrm{kg})$ at harvest time, and dry tuber weight per plot $(\mathrm{kg})$ after drying in indirect sunlight one week later harvest.

Data on shallot farming included the yield and selling price of shallots, fixed costs (land tax, depreciation of agricultural tools and machinery, wages for workers in the family), and variable costs (wages for labor outside the family, cost of seeds, fertilizers, pesticides, and other means of production).

\section{Data Analysis}

The data collected were then analyzed using a two-way analysis of variance (two-way ANOVA) to determine the effect and significant interaction of OPEB compost dosage and goat manure on soil $\mathrm{pH}$, growth, and yield of shallots. Tukey's Honest Significant Difference Test (Tukey's HSD) at the 0.05 level was carried out if there was a significant difference from the observed variables. Meanwhile, the analysis of shallot farming income was performed using the following equation:

$$
\pi=\mathrm{TR}-\mathrm{TC}
$$

where $\pi=$ income $(\mathrm{Rp} /$ year), $\mathrm{TR}=$ total revenue $(\mathrm{Rp} /$ year), and $\mathrm{TC}=$ total cost production (Rp/year). R/C Ratio analysis was done with the formula:

$$
\frac{\mathrm{R}}{\mathrm{C}} \text { Ratio }=\frac{\mathrm{TR}}{\mathrm{TC}}
$$

$\mathrm{R} / \mathrm{C}$ Ratio compares the total revenue gained by the farmer from the selling of shallot and the total production cost spent by the farmer. There are three criteria for the value of the $\mathrm{R} / \mathrm{C}$ Ratio. Ratio value $<1$ means that the farm experiences loss, ratio value $=1$ means that the farm experiences break-even, and ratio value > 1 means that the farm gets profit. This study used two treatments that resulted in the highest shallot yield as the basis for farming income analysis. Those treatments were 5 ton/ha OPEB compost +1.00 ton/ha goat manure and 5 ton/ha OPEFB compost +1.25 ton/ha of goat manure.

The effectiveness of applying compost and manure was measured by calculating Relative Agronomic Relativeness (RAE) as supposed by Indriyati (2018) with modification. Minimum dosage was used as a control. The formula of RAE was then expressed as follows:

$$
\begin{aligned}
& \text { shallot weight }- \text { control }
\end{aligned}
$$

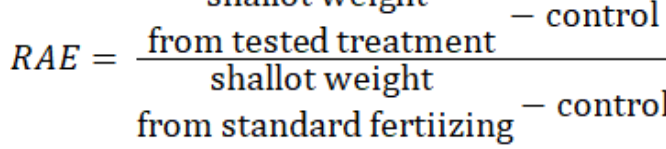

We conducted Pearson correlation analysis to find out the significant correlation between the dosages of compost and manure and the yield of shallot's dry tuber. The correlation coefficient can be determined whether the correlation between the variables was strong or weak.

\section{RESULTS AND DISCUSSIONS}

Table 1 showed $\mathrm{pH}$ analysis of red yellow podzolic soil before treatment application, OPEB compost, and goat manure.

Table 1 showed no significant interaction

Table 1. The $\mathrm{pH}$ of red yellow podzolic soil before treatment application, oil palm empty bunch (OPEB) compost, and goat manure

\begin{tabular}{lll}
\hline Treatment & $\mathrm{pH}$ & Criteria \\
\hline Red yellow podzolic soil & 4.06 & Acid \\
OPEB compost & 8.00 & Base \\
Goat manure & 7.20 & Neutral \\
\hline
\end{tabular}


Table 2. The effect of OPEB compost and goat manure dosages on soil pH, number of leaves, and number of tubers

\begin{tabular}{cccc}
\hline $\begin{array}{c}\text { OPEB compost dosage treatments } \\
\text { (ton/ha) }\end{array}$ & Average soil pH & $\begin{array}{c}\text { Goat manure dosage } \\
\text { treatments } \\
\text { (ton/ha) }\end{array}$ & $\begin{array}{c}\text { Average soil } \\
\text { pH }\end{array}$ \\
\hline 1 & $4.870 \mathrm{a}$ & 0.25 & $4.500 \mathrm{a}$ \\
2 & $5.120 \mathrm{~b}$ & 0.50 & $5.090 \mathrm{~b}$ \\
3 & $5.270 \mathrm{c}$ & $5.460 \mathrm{~cd}$ \\
4 & $5.290 \mathrm{c}$ & 0.75 & $5.540 \mathrm{~d}$ \\
5 & $5.370 \mathrm{c}$ & 1.00 & 1.25 \\
\hline Coefficient of Variance (\%) & 2.13 & & The average of number of \\
leaves \\
OPEB compost dosage & The average of number of & Goat manure dosage & $22.30 \mathrm{a}$ \\
treatments & leaves & treatments & $23.00 \mathrm{a}$ \\
(ton/ha) & (sheets) & 0.25 & $25.20 \mathrm{~b}$ \\
2 & $19.90 \mathrm{a}$ & 0.50 & $27.20 \mathrm{c}$ \\
2 & $22.90 \mathrm{~b}$ & 0.75 & $28.20 \mathrm{c}$ \\
\hline 5 & $25.00 \mathrm{c}$ & 1.00 & 1.25 \\
\hline Variance Coefficient (\%) & $27.20 \mathrm{~d}$ & & The average of number of \\
OPEB compost dosage & $30.90 \mathrm{e}$ & tubers \\
\hline Treatments (ton/ha) & 4.39 & $5.20 \mathrm{a}$
\end{tabular}

Remarks: Means followed by the same lowercase letters are not significantly different according to Tukey's HSD $5 \%$

effect between the dosage of OPEB compost and acidity of RYP soil. The compost has a $\mathrm{pH}$ that goat manure on the soil $\mathrm{pH}$. However, the treat- tends to be alkaline due to $\mathrm{K}_{2} \mathrm{O}$ compounds. In ment of the two fertilizers independently affected the soil, those compounds react with $\mathrm{H}_{2} \mathrm{O}$ and rethe soil $\mathrm{pH}$ significantly. The increasing dosage of lease $\mathrm{OH}$ ions that reduce the number of $\mathrm{H}^{+}$ions, both fertilizers caused the degree of soil acidity to decreasing soil acidity (Ramadhani et al., 2015). decrease and the $\mathrm{pH}$ value to increase.

Asih et al., (2019) confirmed that the increase in

As shown in Table 2, treatment of OPEB at 3 soil $\mathrm{pH}$ of Ultisol type would be more significant tons/ha resulted in the average soil $\mathrm{pH}$ of 5.270, if the OPEB compost were applied over ten years which was not significantly different from the continuously.

application at 4 and 5 tons/ha. Meanwhile, the

In addition, goat manure has a neutral $\mathrm{pH}$ bemanure dosage of 1.00 ton/ha treatment resulted in the average soil $\mathrm{pH}$ of 5.460 , which was not significantly different from the application at 1.25 ton/ha. These values were higher than the soil $\mathrm{pH}$ values produced by fertilizer application at a lower dosage. It is indicated that the higher the fertilizer dosage increase the soil $\mathrm{pH}$. Oil palm empty bunch compost and goat manure, which is alkaline and neutral, are effective enough in neutralizing the cause it contains quite high $\mathrm{K}$ nutrients (Shofiah $\&$ Tyasmoro, 2018). Thus, the manure can increase soil $\mathrm{pH}$ due to the soil organic acid chelation process, in which the $\mathrm{Al}$ element that causes soil acidity can be reduced (Putra et al., 2015). The optimal $\mathrm{pH}$ range for plant growth is 5.6 to 6.0 (Prabowo $\&$ Subantoro, 2017), while for shallot crops, the optimal pH is 5.5 to 6.5 (Arman et al., 2016). If compared with the range of $\mathrm{pH}$ soil after treatment, 
Table 3. The interaction effect of OPEB compost and goat manure on the crop height and number of tillers at the age of 6 WAP

\begin{tabular}{|c|c|c|c|c|c|c|}
\hline \multirow{3}{*}{$\begin{array}{l}\text { OPEB compost dosages } \\
\text { (ton/ha) }\end{array}$} & \multicolumn{5}{|c|}{ Shallot crop height $(\mathrm{cm})$} & \multirow{3}{*}{$\begin{array}{l}\text { The average of } \\
\text { compost treatments }\end{array}$} \\
\hline & \multicolumn{5}{|c|}{ Goat manure dosages (ton/ha) } & \\
\hline & 0.25 & 0.50 & 0.75 & 1.00 & 1.25 & \\
\hline $\begin{array}{l}1 \\
2 \\
3 \\
4 \\
5\end{array}$ & $\begin{array}{l}22.35 \mathrm{a} \\
22.75 \mathrm{ab} \\
23.65 \mathrm{~cd} \\
24.50 \mathrm{f} \\
25.60 \mathrm{~g} \\
\end{array}$ & $\begin{array}{l}22.65 \mathrm{a} \\
23.35 \mathrm{~cd} \\
24.85 \mathrm{f} \\
26.25 \mathrm{~h} \\
26.85 \mathrm{~h} \\
\end{array}$ & $\begin{array}{l}23.00 \mathrm{bc} \\
24.25 \text { ef } \\
24.00 \mathrm{cde} \\
25.85 \mathrm{~h} \\
28.10 \mathrm{i} \\
\end{array}$ & $\begin{array}{l}23.65 \mathrm{~cd} \\
24.40 \mathrm{f} \\
24.90 \mathrm{f} \\
27.75 \mathrm{hi} \\
31.75 \mathrm{j}\end{array}$ & $\begin{array}{l}24.10 \mathrm{e} \\
25.05 \mathrm{fg} \\
25.75 \mathrm{gh} \\
28.90 \mathrm{ij} \\
30.50 \mathrm{j}\end{array}$ & $\begin{array}{l}23.15 \mathrm{a} \\
23.96 \mathrm{ab} \\
24.63 \mathrm{~b} \\
26.69 \mathrm{c} \\
28.56 \mathrm{~d}\end{array}$ \\
\hline $\begin{array}{c}\text { The average of manure } \\
\text { treatments }\end{array}$ & $23.77 a$ & $24.79 b$ & $25,14 b$ & $26.49 c$ & $26.80 \mathrm{c}$ & \\
\hline $\begin{array}{c}\text { Coefficient of Variance } \\
(\%)\end{array}$ & 2.85 & & & & & \\
\hline Treatments & & & er of shallot & & & \\
\hline \multirow{2}{*}{$\begin{array}{l}\text { OPEB compost dosages } \\
\text { (ton/ha) }\end{array}$} & \multicolumn{5}{|c|}{ Goat manure dosages (ton/ha) } & The average of \\
\hline & 0.25 & 0.50 & 0.75 & 1.00 & 1.25 & \\
\hline $\begin{array}{l}1 \\
2 \\
3 \\
4 \\
5\end{array}$ & $\begin{array}{l}3.0 \mathrm{a} \\
4.0 \mathrm{ab} \\
4.5 \mathrm{~b} \\
6.0 \mathrm{~cd} \\
5.5 \mathrm{~cd}\end{array}$ & $\begin{array}{l}3.0 \mathrm{a} \\
4.0 \mathrm{ab} \\
5.0 \mathrm{bc} \\
5.0 \mathrm{bc} \\
6.0 \mathrm{~cd}\end{array}$ & $\begin{array}{l}3.0 \mathrm{a} \\
4.0 \mathrm{ab} \\
5.0 \mathrm{bc} \\
5.0 \mathrm{bc} \\
6.0 \mathrm{~cd}\end{array}$ & $\begin{array}{l}4.0 \mathrm{ab} \\
4.0 \mathrm{ab} \\
5.0 \mathrm{bc} \\
6.0 \mathrm{~cd} \\
8.0 \mathrm{e}\end{array}$ & $\begin{array}{l}5.0 \mathrm{bc} \\
5.0 \mathrm{bc} \\
5.5 \mathrm{~cd} \\
6.5 \mathrm{~d} \\
8.0 \mathrm{e}\end{array}$ & $\begin{array}{l}3.60 \mathrm{a} \\
4.20 \mathrm{~b} \\
5.00 \mathrm{c} \\
5.70 \mathrm{~d} \\
6.70 \mathrm{e}\end{array}$ \\
\hline $\begin{array}{c}\text { The average of manure } \\
\text { treatments }\end{array}$ & $4.60 \mathrm{a}$ & $4.60 \mathrm{a}$ & $4.60 \mathrm{a}$ & $5.40 \mathrm{~b}$ & $6.00 \mathrm{c}$ & \\
\hline $\begin{array}{c}\text { Coefficient of Variance } \\
(\%)\end{array}$ & 5.61 & & & & & \\
\hline
\end{tabular}

Remarks: Means followed by the same lowercase letters are not significantly different according to Tukey's HSD 5\%

which was between 4.5 and 5.5 , the ideal $\mathrm{pH}$ value was achieved when using a manure dosage of 1.25 ton/ha. Due to the relatively short lifespan of the shallot crops (60 days), the observations at increasing soil $\mathrm{pH}$ were very limited.

There was a significant interaction effect of OPEB compost and goat manure on the height of shallot crops at the age of 6 WAP, as can be seen in Table 3. The interaction effect is a combined effect between the compost and manure, which simultaneously influences crop growth or yield.

Interaction effect of 4 ton/ha OPEB compost +1.25 ton/ha goat manure resulted in the highest shallot height (Table 3). However, this result was not significantly different from the results of 5 ton/ ha compost OPEB +1.00 ton/ha of goat manure and 5 ton/ha of OPEB compost +1.25 ton/ha of goat manure, as noted in Table 3. Thus, both fertilizers simultaneously improve crop growth by increasing crop height.

The increase in crop height is part of the vegetative crop growth. Nitrogen $(\mathrm{N})$ is a nutrient that significantly affects vegetative growth. Goat manure, which is high in $\mathrm{N}$ nutrient content (can reach 1-2\%) (Prasetyo, 2014), can be broken down quickly by soil microbial activity so that $\mathrm{N}$ nutrients can be available to plants (Afrilliana et al., 2017). Meanwhile, potassium (K) contained in OPEB compost plays a role in increasing the activity of enzymes in photosynthesis and respiration processes, thereby positively affecting the height increase in shallot crops. K nutrient also contributes to processing protein synthesis in accelerating the conversion of nitrates into protein. That process causes increasing the efficiency of $\mathrm{N}$ fertilization (Alfian et al., 2015). If it is related to the soil pH factor, the decrease in the acidity degree of RYP soil can reduce the fixation of $\mathrm{K}$ elements so that 
Table 4. The interaction of OPEB compost and goat manure on fresh tuber weight at harvest and dry tuber

\begin{tabular}{|c|c|c|c|c|c|c|}
\hline \multirow{3}{*}{$\begin{array}{l}\text { OPEB compost dosages } \\
\text { (ton/ha) }\end{array}$} & \multicolumn{5}{|c|}{ Shallot fresh tuber weight (kg/plot) } & \multirow{3}{*}{$\begin{array}{l}\text { The average of } \\
\text { compost treatments }\end{array}$} \\
\hline & \multicolumn{5}{|c|}{ Goat manure dosages (ton/ha) } & \\
\hline & 0.25 & 0.50 & 0.75 & 1.00 & 1.25 & \\
\hline $\begin{array}{l}1 \\
2 \\
3 \\
4 \\
5\end{array}$ & $\begin{array}{l}0.460 \mathrm{a} \\
0.658 \mathrm{bc} \\
0.840 \mathrm{e} \\
0.950 \mathrm{~h} \\
1.048 \mathrm{i}\end{array}$ & $\begin{array}{l}0.512 \mathrm{a} \\
0.668 \mathrm{bc} \\
0.842 \mathrm{eh} \\
1.036 \mathrm{i} \\
1.010 \mathrm{hi}\end{array}$ & $\begin{array}{l}0.518 \mathrm{a} \\
0.712 \mathrm{c} \\
0.884 \mathrm{fh} \\
1.010 \mathrm{hi} \\
1.470 \mathrm{i}\end{array}$ & $\begin{array}{l}0.528 \mathrm{ac} \\
0.724 \mathrm{~d} \\
0.918 \mathrm{gh} \\
1.042 \mathrm{i} \\
1.650 \mathrm{i}\end{array}$ & $\begin{array}{l}0.652 \mathrm{bc} \\
0.828 \mathrm{~d} \\
0.970 \mathrm{hi} \\
1.086 \mathrm{i} \\
2.020 \mathrm{j}\end{array}$ & $\begin{array}{l}0.534 \mathrm{a} \\
0.718 \mathrm{~b} \\
0.891 \mathrm{c} \\
1.025 \mathrm{~d} \\
1.513 \mathrm{e}\end{array}$ \\
\hline $\begin{array}{c}\text { The average of manure } \\
\text { treatments }\end{array}$ & $0.791 \mathrm{a}$ & $0.887 \mathrm{~b}$ & $0.919 b c$ & $0.972 \mathrm{c}$ & $1.111 d$ & \\
\hline $\begin{array}{c}\text { Coefficient of Variance } \\
(\%)\end{array}$ & 6.76 & & & & & \\
\hline Treatments & \multicolumn{5}{|c|}{ Shallot dry tuber weight (kg/plot) } & \multirow{3}{*}{$\begin{array}{c}\text { The average of } \\
\text { compost treatments }\end{array}$} \\
\hline \multirow{2}{*}{$\begin{array}{l}\text { OPEB compost dosages } \\
\text { (ton/ha) }\end{array}$} & \multicolumn{5}{|c|}{ Goat manure dosages (ton/ha) } & \\
\hline & 0.25 & 0.50 & 0.75 & 1.00 & 1.25 & \\
\hline $\begin{array}{l}1 \\
2 \\
3 \\
4 \\
5\end{array}$ & $\begin{array}{l}0.216 \mathrm{a} \\
0.352 \mathrm{bc} \\
0.464 \mathrm{e} \\
0.578 \mathrm{e} \\
0.532 \mathrm{e}\end{array}$ & $\begin{array}{l}0.250 \mathrm{ab} \\
0.366 \mathrm{bc} \\
0.464 \mathrm{e} \\
0.578 \mathrm{e} \\
0.732 \mathrm{~g}\end{array}$ & $\begin{array}{l}0.278 \mathrm{bc} \\
0.376 \mathrm{~cd} \\
0.446 \mathrm{e} \\
0.466 \mathrm{e} \\
0.922 \mathrm{~g}\end{array}$ & $\begin{array}{l}0.284 \mathrm{bc} \\
0.412 \mathrm{de} \\
0.454 \mathrm{e} \\
0.708 \mathrm{fg} \\
0.918 \mathrm{~g}\end{array}$ & $\begin{array}{l}0.384 \mathrm{~d} \\
0.726 \mathrm{~g} \\
0.478 \mathrm{e} \\
0.593 \mathrm{ef} \\
0.990 \mathrm{~g}\end{array}$ & $\begin{array}{l}0.282 a \\
0.446 b \\
0.461 b \\
0.585 c \\
0.805 d\end{array}$ \\
\hline $\begin{array}{l}\text { The average of manure } \\
\text { treatments }\end{array}$ & $0.428 a$ & $0.478 a b$ & $0.498 a b$ & $0.555 \mathrm{bc}$ & $0.620 c$ & \\
\hline $\begin{array}{c}\text { Coefficient of Variance } \\
(\%)\end{array}$ & 16.12 & & & & & \\
\hline
\end{tabular}

Remarks: Means followed by the same lowercase letters are not significantly different according to Tukey's HSD 5\%

the availability of $\mathrm{K}$ in the RYP soil will increase (Gunawan et al., 2019).

Table 2 indicated no significant interaction effect of OPEB compost and goat manure on the number of leaves of shallot crops. Both treatments also significantly affected the number of crop leaves independently. The application of OPEB compost at a 5 ton/ha dosage resulted in the most significant number of leaves of 30.90 at $6 \mathrm{WAP}$, compared to the other four dosages. Meanwhile, the most significant number of leaves resulting from the goat manure application was obtained at a 1.00 and 1.25 ton/ha dosage.

An increase in the dosage of OPEB compost and goat manure caused a significant increase in the number of leaves of shallot crops (Table 2). The $\mathrm{N}$ nutrient found in goat manure plays a direct role in synthesizing amino acids, proteins, nucleic acids, enzymes, nucleoproteins, and alkaloids needed in the vegetative growth of crops, in this case, the formation of leaves and increase in leaf green color. The addition of K in RYP soil through the application of OPEB compost can stimulate physiological processes in crops in the form of enzyme activity, protein synthesis, and cell enlargement (Suwandi et al., 2015). That process causes an increase in the number of leaves, and the formation of chlorophyll causes the color of the leaves to become greener.

The number of tillers at the age of 6 WAP, as demonstrated in Table 3, was significantly influenced by OPEB compost and goat manure treatments. There was also a significant interaction between both treatments on the number of tillers. The application of 1.00 and 1.25 ton/ha OPEB compost combined with 1.00 ton/ha of goat manure resulted in the largest number of tillers per cluster. Combining other treatments with a smaller fertilizer dosage resulted in fewer tillers. Simultane- 
Table 5. Profit analysis of organic shallot farming

\begin{tabular}{|c|c|c|c|}
\hline \multirow{2}{*}{ No. } & \multirow{2}{*}{ Description } & \multicolumn{2}{|l|}{ Value per hectare (IDR) } \\
\hline & & Fertilization treatment type 1 & Fertilization treatment type 2 \\
\hline 1. & Production (kg/ha) & 3,060 & 3,300 \\
\hline 2. & Selling price $(\mathrm{Rp} / \mathrm{kg})$ & 35,000 & 35,000 \\
\hline 3. & Total revenue & $107,000,000$ & $115,500,000$ \\
\hline 4. & Cost production: & & \\
\hline \multirow[t]{4}{*}{ a. } & Fixed cost & & \\
\hline & 1) Land tax & 100,000 & 100,000 \\
\hline & 2) Depreciation of tools and machines & $1,550,525$ & $1,550,525$ \\
\hline & Total fixed cost & $1,650,525$ & $1,650,525$ \\
\hline \multirow[t]{6}{*}{ b. } & & & \\
\hline & $\begin{array}{l}\text { 1) Seedlings } \\
\text { 2) OPEB compost }\end{array}$ & $30,000,000$ & $30,000,000$ \\
\hline & 3) Goat manure & $5,000,000$ & $5,000,000$ \\
\hline & $\begin{array}{l}\text { 4) Pesticides } \\
\text { 4) Poate }\end{array}$ & $4,000,000$ & $5,000,000$ \\
\hline & $\begin{array}{l}\text { 4) Pesticiaes } \\
\text { 5) Labors }\end{array}$ & $2,500,000$ & $2,500,000$ \\
\hline & Total variable cost & $\begin{array}{l}24,500,000 \\
66,000,000\end{array}$ & $24,500,000$ \\
\hline c. & Total cost production & $67,650,525$ & $68,650,525$ \\
\hline 5. & Net profit & $39,349,475$ & $46,849,475$ \\
\hline 6. & R/C Ratio & 2.719 & 2.465 \\
\hline
\end{tabular}

ously, the use of OPEB compost and manure on RYP soil can increase the number of tillers formed in each cluster of shallot crops.

The data in Table 3 demonstrate that the increasing dosages of fertilizer applied to RYP soil encourage the formation of more tillers per cluster. If it is related to the growth of crop leaves, the more leaves that are formed, the more tillers will be produced. The greater number of leaves and amount of photosynthate improved the growth, development of crops, and storage of food reserves. According to Purba (2016), photosynthesis is distributed from leaves to all plant parts, especially meristem tissue at growing points and tubers that are starting to develop. The photosynthate accumulation in the tubers causes the tubers to form tillers, rising to form clusters of shallot bulbs.

Table 2 showed that the application of OPEB compost and goat manure significantly affected the number of shallot tubers at harvest. However, there was no significant interaction effect on the number of shallot tubers per cluster. The application of OPEB at 5 tons/ha produced the largest number of tubers (7.70 tubers per cluster). Meanwhile, the goat manure application at a 1.00 ton/ ha dosage was not significantly different from the application of 1.25 ton/ha. The interaction effect was not observed, which is assumed to be due to the development of each nutrient in each type of fertilizer that is stronger than when the nutrients work simultaneously, particularly when the crops enter the generative phase.

In general, it can be seen that the increasing dosages of fertilizer on RYP soil cause the number of shallot tillers to increase, in which more tillers will increase the number of tubers per cluster of shallot crops. Afrilliana et al., (2017) stated that the number of lateral shoots in the seedlings would determine the number of tubers formed, where calyx that changed function would form new tubers, which when enlarged would produce shallotcoated tubers. Furthermore, Afriliana et al., (2017) confirmed that crop genetic factors influenced the number of tillers and the number of shallot tubers. Still, the inherited properties could be affected by external factors, including the addition of nutrients to the soil as the planting medium.

Alfian et al., (2015) argued that the number of tubers formed in shallot crops was influenced by the crop variety and availability of nutrients, in 


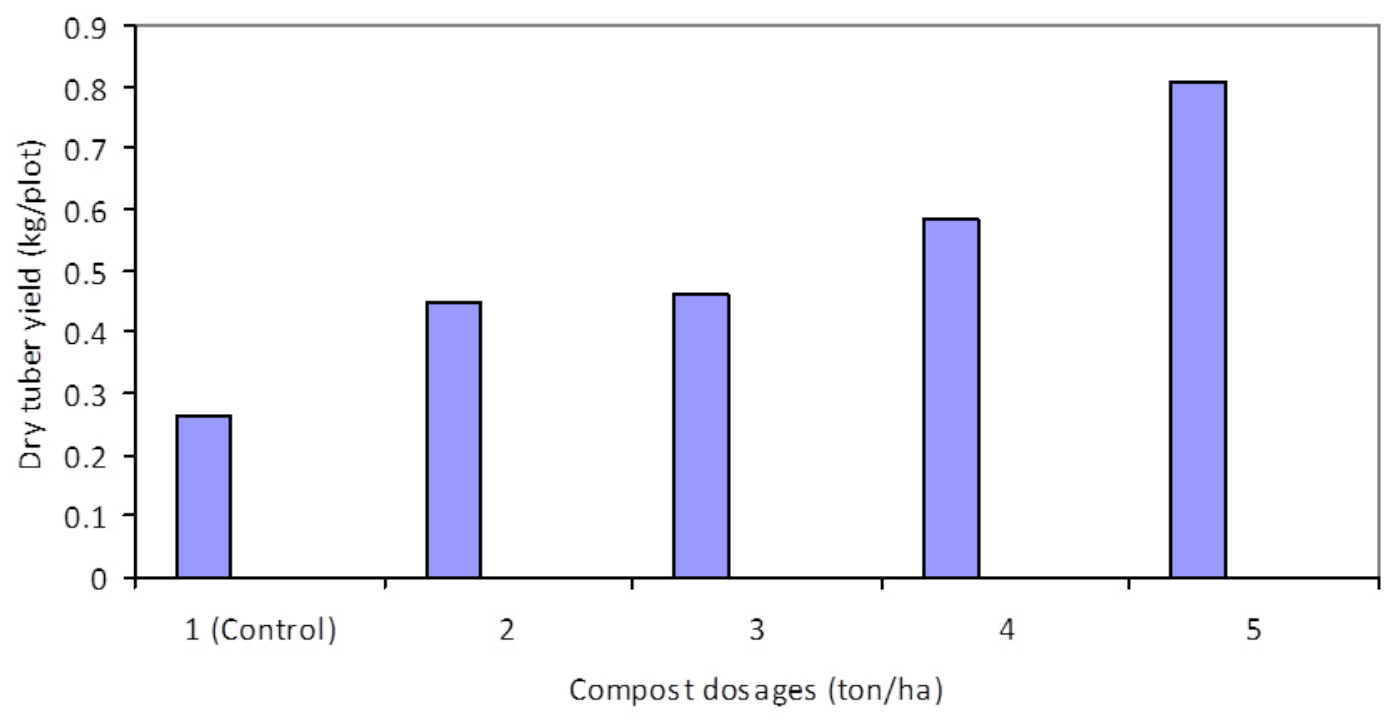

Figure 1. The relationship between compost dosages and shallot's yields

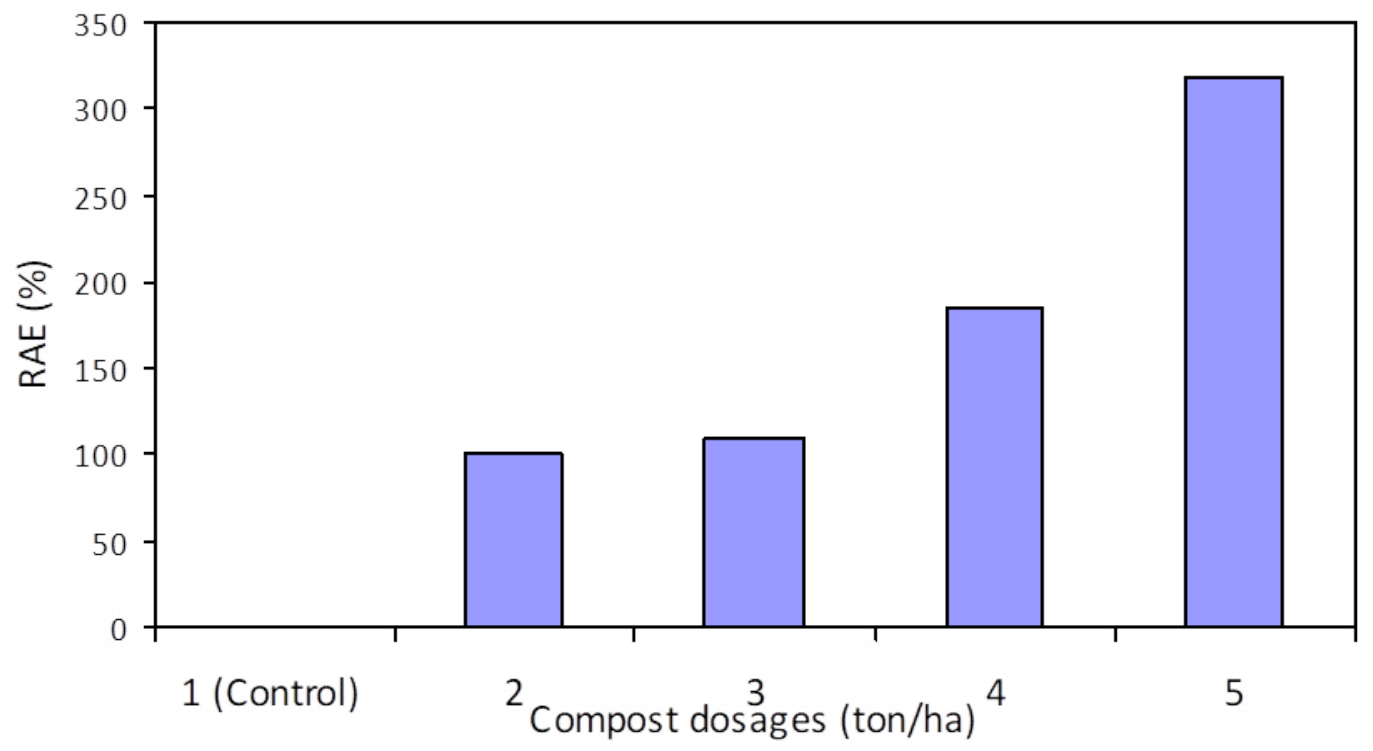

Figure 2. The RAE value of compost application on shallot's yields

this case, the $\mathrm{K}$ element. Crops use $\mathrm{K}$ nutrients to synthesize amino acids and proteins from ammonium ions. In addition, the $\mathrm{K}$ element also serves in increasing the metabolic process of crops in the forms of cell enlargement and the transportation of photosynthetic products (assimilates) from the leaves through the phloem (filter vessels) as a transport network to the reproductive organ tissues, that is, shallot tubers. The greater the accumulation of assimilates in the tubers will encourage the formation of an increasing number of tubers. The tubers that are formed in shallot crops are the result of calyx inflating. Thus, there is a close relationship between the number of tubers formed and the number of shallot leaves (Hidayat et al., 2010).

Table 4 showed that the weight of fresh shallot tubers at harvest time was significantly influenced by the application of OPEB compost and goat 


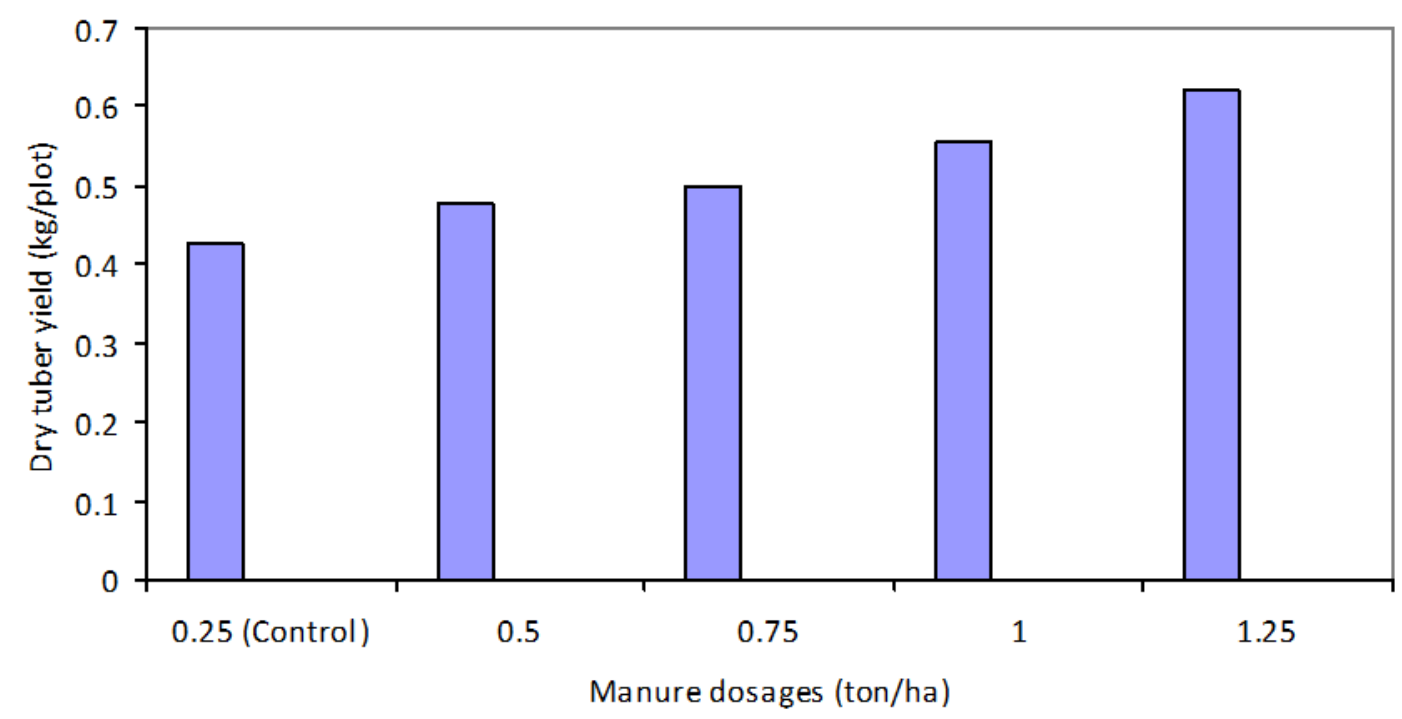

Figure 3. The relationship between manure dosages and shallot's yields

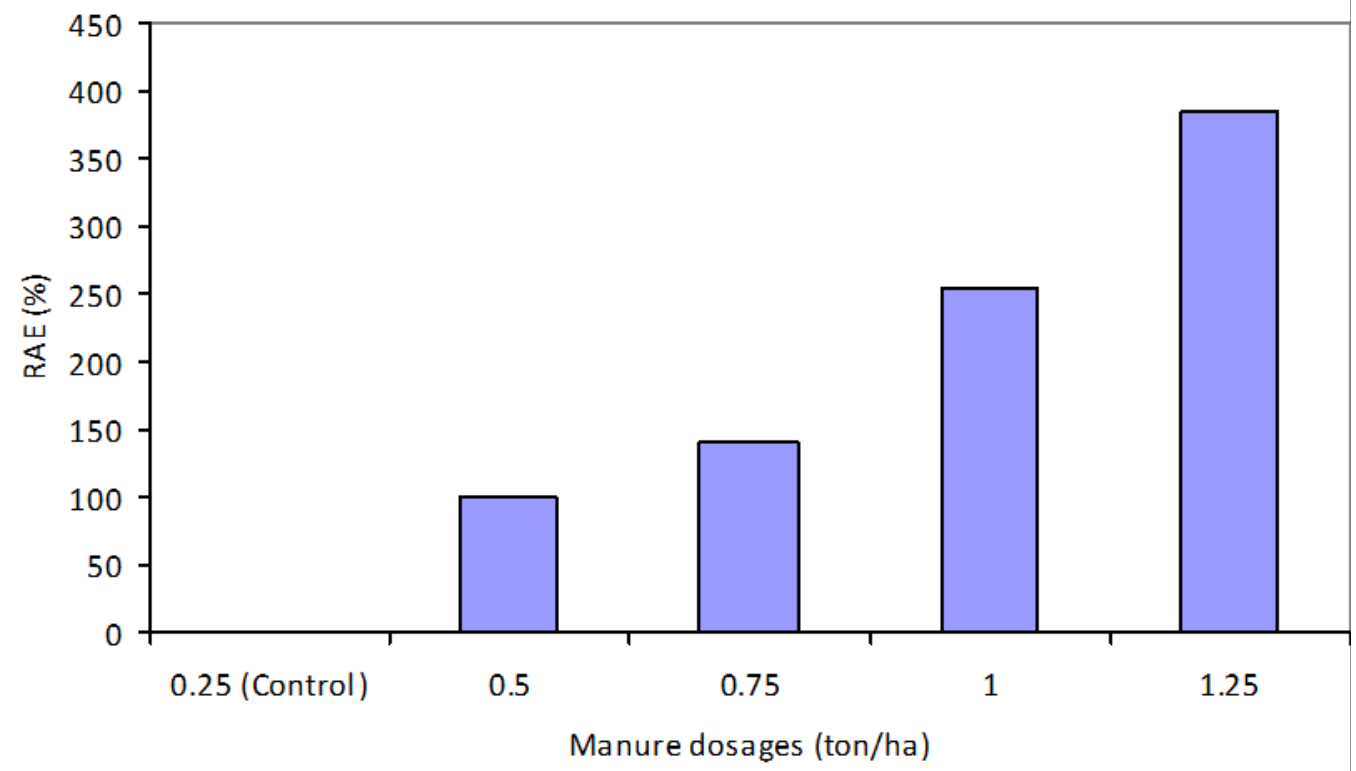

Figure 4. The RAE value of manure application on shallot's yields

manure. Both treatments also generated a signifi- the fresh tuber weight of shallot crops. This simulcant interaction effect on fresh tuber weight. The taneous effect points out a balance of nutrients in combination of 5 ton/ha of OPEB compost +1.25 the RYP soil needed for crop growth. $\mathrm{N}$ nutrient ton/ha of goat manure resulted in the highest fresh in goat manure improves crop vegetative growth, tuber weight $(2.020 \mathrm{~kg} / \mathrm{plot})$. encouraging a better generative phase. Meanwhile,

A study by Napitupulu \& Winarto (2010) indi- the presence of K nutrient in RYP soil plays a very cated an interaction effect of $\mathrm{N}$ and $\mathrm{K}$ fertilizers on important role in synthesizing carbohydrates and 
protein, which leads to tuber size enlargement and increases fresh tuber weight. Goat manure also contains $0.8 \%$ phosphorus (P) (Prasetyo, 2014), where crops use $\mathrm{P}$ elements to form cell nuclei, to help the process of cell division, and to increase the number of cells, as well as to serve as a regulator of photosynthate distribution between sources and reproductive organs (Arman et al., 2016). P element in the RYP soil also functions in shallot tubers' enlargement and weight gain.

The application of OPEB compost and goat manure significantly affected the weight of dry tubers of shallot crops, as pointed out in Table 4. Both treatments also have a significant interaction effect on the weight of shallots dried for one week after harvest. The combination of 4 ton/ha OPEB compost +1.00 ton/ha of goat manure was not significantly different from the results of several treatment combinations with higher dosages, such as the combination of 5 ton/ha OPEB compost + 0.50 ton/ha goat manure, the combination of 5 ton/ha OPEB compost +0.75 ton/ha goat manure, the combination of 5 ton/ha OPEB compost +1.00 ton/ha goat manure, and the combination of 5 ton/ha OPEB compost + 1.25 ton/ha goat manure.

The yields of dry tubers from the treatment combinations considered optimal could exceed the production in the level of farmers around the research location as many as 0.76 tons/ha. However, this productivity value is still below the average shallot production in Central Sulawesi, reaching 5.31 tons/ha (Sulteng, 2017). The factor that is assumed to have contributed to this difference in productivity is the tenuous spacing used for planting, namely $20 \mathrm{~cm} \times 30 \mathrm{~cm}$ (Table 4). Alfian et al., (2015) indicated that a denser spacing such as 10 $\mathrm{cm} \times 10 \mathrm{~cm}$ would lead to a lower soil evaporation rate and reduce the risk of nutrient loss. Thus, nutrients will be optimally available to meet the needs of crops.

Farming economic analysis was carried out to determine the net profit from shallot farming, which applies OPEB compost organic fertilizer and fermented goat manure on RYP soil. This analysis was designed for shallot farming on a 1-hectare scale using a combination of fertilizer treatment of 5 ton/ha OPEB compost +1.00 ton/ha goat manure as fertilization treatment type 1 and the combination of 5 ton/ha OPEFB compost +1.25 ton/ha of goat manure as fertilization treatment type 2 (Table 5). This analysis model assumes that farmers only use organic fertilizers as an alternative to the use of chemicals, including synthetic chemical fertilizers on soil and crops (Vebriyanti et al., 2018). The analysis results in the form of profit calculations and the $\mathrm{R} / \mathrm{C}$ value of organic shallot farming are shown in Table 9.

The calculation results in Table 9 show that organic shallot farming provides a net profit of IDR 39,349,475/ha (fertilizer treatment type 1) and IDR 46,849,475/ha (fertilizer treatment type 2). The $\mathrm{R} / \mathrm{C}$ ratio values, respectively 2.719 and 2.465 , mean that farming is economically feasible because every 1-unit cost will provide more than two revenue units. The value of $\mathrm{R} / \mathrm{C}$ Ratio in fertilization treatment type 1 is greater than the $\mathrm{R} / \mathrm{C}$ ratio in treatment type 2 because the total production cost incurred is smaller, especially for fertilization expense. Thus, although the profit obtained in fertilization type 1 is less, the R/C Ratio value is greater than that of type 2 .

Relative Agronomic Effectiveness (RAE) analysis to determine the effectiveness of organic fertilizer application was conducted on the shallot's dry tuber. According to Table 8, the application of compost dosages of $2,3,4$, and 5 ton/ha resulted in a significantly different yield of shallot's dry tuber compared to the application of a minimum 
compost dosage of 1 ton/ha. The results of the RAE analysis point out that the effectiveness of organic compost in increasing the yield of shallot's dry tubers ranges from $100 \%$ to $318.90 \%$. According to correlation analysis, the Pearson correlation coefficient was 0.964 with a significance of 0.008 . The correlation coefficient was significant at a confidence level of 0.95 means there was a very strong correlation between compost dosages and shallots' dry tuber yield.

The Relative Agronomic Effectiveness (RAE) value effectively measures a fertilization treatment application compared to the fertilization standard measure (Indriyati, 2018). The results show that the effectiveness of organic fertilization increases when the fertilizer dosage is also increased. In fertilization using compost, the highest RAE value of $318.90 \%$ was obtained at the 5 ton/ha compost dosage. Compared with the standard treatment with an RAE value of $100 \%$, there was an increase in the effectiveness of $218.90 \%$. The more effective fertilization will eventually lead to an increase in crop yields. The yield of shallot's dry tubers at compost dosage of 1 ton/ha was $0.282 \mathrm{~kg} /$ plot (0.94 ton/ ha), while the yield at the compost dosage of 5 ton/ ha was $0.805 \mathrm{~kg} /$ plot (2.68 ton/ha), indicating an increase in the yield of dry tubers of $185.46 \%$.

The application of goat manure with the highest dosage of 1.25 ton/ha also gave the highest dry tuber yields $(0.620 \mathrm{~kg} / \mathrm{plot})$, which was not significantly different from the results of compost dosage of $1.00 \mathrm{ton} /$ ha (Table 8 ). However, the results of RAE analysis indicated that manure application was able to incline the yield of dry tubers, which was greater than the compost application, which was between $100 \%$ and $384 \%$.

The RAE value in manure application also points out an increase along with fertilizer dosage. The highest RAE value was obtained at the dosage of 1.25 ton/ha manure, $384 \%$, showing an effec- tiveness increase of $284 \%$ compared to standard treatment with an RAE value of $100 \%$. The yield of dry tubers at the dosage of 0.25 ton/ha manure was $0.428 \mathrm{~kg} /$ plot $(1.43 \mathrm{ton} / \mathrm{ha})$, while the dry tuber yields at the dosage of $1.25 \mathrm{ton} /$ ha manure were $0.620 \mathrm{~kg} / \mathrm{plot}$ (2.07 ton/ha), indicating a yield enhancement of $44.86 \%$. Thus, an increase in the effectiveness of manure will cause addition in the yield of dry tubers. Correlation analysis suggested that the value of the Pearson correlation coefficient was 0.986 . The significance of the correlation was 0.002 , which was significant at a confidence level of 0.95 . A very strong correlation was then indicated between manure dosages and the yield of dry tubers.

The application of organic compost and manure effectively improved soil fertility by enhancing the amount of soil organic matter in organic C, reducing the acidity of red yellow podzolic soil, and increasing soil microbial activities. The improvement of soil fertility causes improvements in crop growth processes, where root growth takes place optimally to facilitate the absorption of nutrients from the soil. Adequate absorption of nutrients will ultimately increase crop yields (Indriyati, 2018).

\section{CONCLUSION}

The combination of 5 ton/ha of compost and 1.25 ton/ha of goat manure yielded the highest dry tuber production of $0.990 \mathrm{~kg} /$ plot (3.30 ton/ ha). Organic shallot farming on RYP soil provides profit with an R/C Ratio > 1, so the farming is economically feasible. The highest effectiveness of compost application was obtained at the dosage of 5 tons/ha. While the highest effectiveness of manure application at the dosage of 1.25 tons/ ha. A very strong correlation is found between the organic fertilizers and shallot's dry tuber yield. 


\section{ACKNOWLEDGEMENTS}

Gratitude and appreciation are expressed to the Directorate of Research and Community Service (Direktorat Riset dan Pengabdian Masyarakat/ DRPM), Indonesian Ministry of Research and Technology-National Research and Innovation Agency (Kementerian Riset dan Teknologi RIBadan Riset dan Inovasi Nasional/KemristekBRIN) for funding this research through the scheme of Beginner Lecturer Research (Penelitian Dosen Pemula/PDP) in the year of 2020.

\section{REFERENCES}

Afrilliana, N., Darmawati, A., \& Sumarsono. (2017). The growth and yields of shallot (Allium ascalonicum L.) affected by $\mathrm{KCl}$ fertilizer addition based on different organic fertilizers. Agro Complex, 1(3), 126-134. https://doi.org/https://doi.org/10.14710/ joac.1.3.126-134

Alfian, D. F., Nelvia, \& Yetti, H. (2015). The effect of potassium fertilizer and compost mixture of oil palm empty bunches with boiler ash on growth and yield of onion (Allium ascalonicum L.). Agroteknologi, 5(2), 1-6. https://doi.org/http://dx.doi. org/10.24014/ja.v5i2.1348

Arman, Z., Nelvia, \& Armaini. (2016). Physiological responses, growth, production and $P$ uptake by shallots (Allium ascalonicum L.) against application of trichompos oil palm empty fruit bunch (PEFB) formulated and P fertilizer on peatlands. Agroteknologi, 6(2), 15-22. https://doi.org/http://dx.doi.org/10.24014/ ja.v6i2.2236

Asih, P. W., Utami, S. R., \& Kurniawan, S. (2019). Changes in soil chemical properties after application of oil palm empty fruit bunch on two soil texture classes. Tanah Dan Sumberdaya Lahan, 6(2), 1313-1323. https://doi.org/10.21776/ub.jtsl.2019.006.2.12

Elfiati, D., \& Siregar, E. B. M. (2010). Utilization of empty palm bunches as mixed growth media and application of mycorrhizae for mindi seeds (Melia azedarach L.). Hidrolitan, 1(3), 11-19. https://online-journal.unja.ac.id/hidrolitan/article/view/461

Erpina, l., Linda, R., \& Setyawati, T. R. (2013). The growth of hybrid chili (Capsicum annuum $L$.) on the combination of PMK soil and TKKS waste compost. Protobiont, 2(2), 19-25. https://doi.org/ http://dx.doi.org/10.26418/protobiont.v2i2.2718

Firmansyah, A. (2010). Composting technique. http://kalteng.litbang. pertanian.go.id/ind/images/data/teknik-kompos.pdf

Gunawan, Wijayanto, N., \& Budi, S. W. (2019). Characteristics of soil chemical properties and soil fertility status of vegetables agroforestry based on Eucalyptus sp. Silvikultur Tropika, 10(2), 63-69. https://journal.ipb.ac.id/index.php/jsilvik/article/view/28722

Hidayat, F., Sugiarti, U., \& Chandra, K. A. (2010). Giving influence of bokashi from jelly solid waste and inorganic fertilizer to growth and produce of onion crop (Allium ascalonicum L.) variety Philipina. Agrika, 4(1). https://doi.org/DOI: https://doi. org/10.31328/ja.v4i1.145

Indriyati, L. T. (2018). Effectiveness of organic and inorganic fertilizers on the growth and yield of broccoli (Brassica oleracea var. Italica). Jurnal IImu Pertanian Indonesia, 23(3), 196-292. https:// doi.org/10.18343/jipi.23.3.196

Kurniawan, R., Lahay, R. R., Silitonga, S., \& Hanum, C. (2014). Sweet corn growth and production with application microorganism and empty fruit bunches oil palm compost. Online Agroteknologi, 2(3), 1172-1181. https://doi.org/10.32734/jaet.v2i3.7508

Kusuma, M. E. (2012). The effect of some kind of manure to bokashi quality. IImu Hewani Tropika, 1(2), 41-46. https://www. unkripjournal.com/index.php//IHT/article/view/13

Napitupulu, D., \& Winarto, L. (2010). The effect of $\mathrm{N}$ and $\mathrm{K}$ fertilizer on growth and yield of shallots. Hortikultura, 20(1), 27-35. https://doi.org/http://dx.doi.org/10.21082/jhort. v20n1.2010.p\%25p

Prabowo, R., \& Subantoro, R. (2017). Soil analysis as an indicator of the fertility level of agricultural cultivation land in the city of Semarang. Cendekia Eksakta, 2(2), 59-64. https://doi.org/ http://dx.doi.org/10.3194/ce.v2i2.2087

Prasetyo, R. (2014). Utilization of various sources of manure as a source of $\mathrm{N}$ in red chili cultivation in sandy soil. Planta Tropika: Journal of Agro Science, 2(2), 125-132. https://doi.org/https:// doi.org/10.18196/pt.2014.032.125-132

Purba, R. (2016). Study of the use of organic fertilizer in shallot farming system in Serang Banten. Planta Tropika: Journal of Agro Science, 4(1), 1-6. https://doi.org/DOl: https://doi. org/10.18196/pt.2016.049.1-6

Putra, A. D., Damanik, M., \& Hanum, H. (2015). Urea fertilizer and goat manure application for increasing $\mathrm{N}$-total on inceptisol Kuala Bengkala and corn growth (Zea mays L.). Online Agroteknologi, 3(1), 128-135. https://doi.org/10.32734/jaet.v3i1.9373

Raiwani, R., Burhanuddin, \& Darwati, H. (2016). Effect of organic fertilizer cow dung on the growth nyamplung (Calophyllum inophyllum Linn) on ultisol soil. Hutan Lestari, 4(4), 596-604. https://doi.org/DOl: http://dx.doi.org/10.26418/jhl.v4i4.18246

Ramadhani, F., Aryanti, E., \& Saragih, R. (2015). Utilization of several types and dosages of palm oil waste on changes in $\mathrm{pH}, \mathrm{N}, \mathrm{P}$, $\mathrm{K}$ of red yellow podzolic soil. Agroteknologi, 6(1), 9-16. https:// doi.org/http://dx.doi.org/10.24014/ja.v6i1.1371

Regency, B. S. of P. (2017). Poso Regency in Figures 2017 (B. P. S. K. Poso (ed.)). Badan Pusat Statistik Poso. https://posokab.bps. go.id/publication/2017/08/13/f47d7c34ec4a6c35ce37e456/ kabupaten-poso-dalam-angka-2017.html

Shofiah, D. K. R., \& Tyasmoro, S. Y. (2018). Application of PGPR (Plant Growth Promoting Rhizobacteria) and goat manure on growth andd yield of shallot (Allium ascalonicum L.) Manjung variety. Produksi Tanaman, 6(1), 76-82. http://protan.studentjournal. ub.ac.id/index.php/protan/article/view/617

Sukasih, N. S. (2017). The effect of palm oil empty bunch compost on the growth and yield of leek crop (Allium fistolosum L.). Publikasi Informasi Pertanian, 13(24), 39-52. http://jurnal.unka. ac.id/index.php/piper/article/view/66

Sulteng, B. (2017). Central Sulawesi Province in Figures of 2017 (B. I. dan P. D. Statistik (ed.)). Badan Pusat Statistik Provinsi Sulawesi Tengah. https://sulteng.bps.go.id/publication/2017/08/11/35 5b7acc700bd2e89afd0084/provinsi-sulawesi-tengah-dalam- 
angka-2017.html

Sumarni, N., Rosliani, R., Basuki, R. S., \& Hilman, Y. (2012a). Effects of varieties, soil-K status, and $K$ fertilizer dosages on plant growth, bulb yield, and $\mathrm{K}$ uptake of shallots plant. Hortikultura, 22(3), 233-241. https://doi.org/http://dx.doi.org/10.21082/ 息ort.v22n3.2012.p233-241

Sumarni, N., Rosliani, R., \& Suwandi, -. (2012b). Optimization of plant distance and NPK dosage to produce shallots from shallots set in highland. Hortikultura, 22(2), 147-154. http://ejurnal.litbang. pertanian.go.id/index.php/jhort/issue/view/202

Suwandi, Sopha, G. A., \& Yufdy, M. P. (2015). The effectiveness of organic fertilizer, NPK, and biofertilizer managements on growth and yields of shallots. Hortikultura, 25(3), 208-221. https:// doi.org/DOl: http://dx.doi.org/10.21082/jhort.v25n3.2015. p208-221

Tando, E. (2020). Efforts to increase the productivity of peanut crop and improve the fertility of red yellow podzolic soil through the use of biochar technology in Southeast Sulawesi. Agroradix, 3(2), 15-22. http://e-jurnal.unisda.ac.id/index.php/ agro/article/view/1953

Vebriyanti, D., Antara, M., \& Effendy. (2018). Analysis of comparative production and income farm onion organic and non organic in Oloboju Village Sigi Biromaru Sub-district Sigi Regency. Agroland: Jurnal IImu-IImu Pertanian, 25(3), 259-264. http://jurnal. untad.ac.id/index.php/AGROLAND/article/view/11963 